UDC 929:821 Bigsby C.

https://doi.org/10.18485/bells.2017.9.12

Radojka Vukčević

\title{
AN INTERVIEW WITH CHRISTOPHER BIGSBY
}

Christopher Bigsby, a Fellow of the Royal Society of Literature and the Royal Society of Arts, is an award winning academic, novelist and biographer. His first novel, Hester, won the McKitterick Prize. Beautiful Dreamer (2002) was an American Library Association Notable Book. With Don Wilmeth, he won the Bernard Hewitt Award for Outstanding Research in Theatre History and the George Freedley Jury Award for the Cambridge History of the American Theatre. He has also received the 'NAFSA Education Abroad Leadership Award'. His biography of Arthur Miller was shortlisted for the James Taite Black Memorial Prize, the Sheridan Morley Prize and the George Freedley Memorial Award. It was a CHOICE Outstanding Academic Title for 2009 and was joint winner of the American Studies network Award. His is also winner of the Betty Jean Jones Award for Outstanding Teacher of American Theatre and Drama.

As a broadcaster, he presented Radio 4's Kaleidoscope for over eight years, as well as Radio 3's Third Ear and Radio 4's Off the Page. He was also presenter of Radio 3's First Night and Radio 4's Present Voices, Past Words and The Index as well as presenting editions of The Archive Hour and Centurions. He has made television programmes on John Steinbeck, Mark Twain, and Edith Wharton. He has reviewed for a number of national newspapers (including The Guardian, The Independent and The Daily Telegraph) and his programme notes have appeared in theatres throughout the UK, in Australia, Canada and the United States. For 18 years he was Director of the British Council's flagship Cambridge Seminar and has travelled widely on its behalf. 
He has published some fifty books, including a recent two-volume biography of Arthur Miller and his latest novel, 'The Hotel'. ${ }^{1}$

Christopher Bigsby has agreed to speak for Belgrade BELLS in September 2016 during Salzburg Seminar, where I was privileged to meet him.

BELLS: It is well-known that you have published some fifty books in familiar fields, which is more than impressive. It is even more impressive that you have given a great contribution to each of them. As an award winning academic, novelist and biographer, you have devoted yourself to many fields: American drama, literature and culture; British popular culture; media; fiction writing, etc. How would you rank your interest in them?

CHRISTOPHER BIGSBY: As you will see from my CV, I have bounced around somewhat in my interests, though the American theatre has taken up much of my time. This may seem eccentric, probably is eccentric, in that immediately to hand is a British theatre which is a deal more convenient. I have written about Joe Orton and Stoppard, while editing a book on the English theatre. I also personally know quite a number of British playwrights and am even an off-stage character in a Pinter play. Knowing how sinister they can be I asked him what this character was like. He said, 'don't worry. He's alright.'

BELLS: Is it possible to describe the pathways of your contributions to each of these fields? Can we say that each decade in your academic writing has been following what was going on in the world of writing.

CHRISTOPHER BIGSBY: I got interested in the American theatre when I spent a year as a Fulbright student in, of all places, Kansas State University - don't ask - where I saw a student production of Albee's The Zoo Story. I was bowled over by this and drove, with some friends a hundred miles or more to see the road version of Who's Afraid of Virginia Woolf? A few years later I wrote a book about him and got to know him personally, as I would, in time, David Mamet and Arthur Miller. I would write a three-volume introduction to the American theatre, but before doing so wrote The Second Black Renaissance, about African-American novels,

1 The short bibliographical note was taken from http://www.christopherbigsby.com/ 
plays and poetry from Richard Wright onwards, having previously been interested in black writing, early on editing a two-volume collection of essays. In time I would meet and interview a fair number of black writers including James Baldwin, Ralph Ellison, Amiri Baraka, Alice Walker and Toni Morrison - once dancing with the last in a bodega in Spain! I got to know a number of writers because for a number of years I worked on the side for the BBC, domestically and on World Service. Somewhere along the line I wrote a book about Dada and Surrealism, a subject on which I knew nothing (it is about to be re-issued), and edited a couple of books on popular culture because I had always believed that the best way to study a culture is to look at its popular culture, something to which I would return many decades later when I wrote a book about American television drama because suddenly, and to many people's surprise, quality television was coming from a country which had not specialised in such for many decades. I wrote a book about Holocaust writing because I started to write a book commemorating W.G. Sebald, a friend and colleague here at UEA, and got sidelined as I followed his interest in other writers. So, as you will see, my career was not planned but had a fair degree of serendipity about it. I would jump from subject to subject. I have just finished a book for CUP on $21^{\text {st }}$ Century American playwrights, largely because I realised that I had got out of touch and needed to tune in again.

BELLS: Apart from significant academic writing, you have been working on a very special mission: popularizing the world of writing through other media, such as radio and TV. How do you see the present moment in the light of this relatively recently recognized important connection?

CHRISTOPHER BIGSBY: As to my work in radio and TV, this now largely lies in the past though I was heavily involved for many years presenting a whole range of programmes, not always involving writers. This occasionally took me to the States and Canada. This was how I got to know Joseph Heller and Margaret Atwood, the latter when I was making a programme about the arts in Toronto. I took her out for dinner and only realised when the bill was presented that I had left my wallet in the hotel so that she had to pay. I did make up for it later when she came to UEA and I could take her out, this time not relying on her to shell out. I've never much liked appearing in GTV, which I have done very infrequently. I did, though, make an interesting programme about Mark Twain whose Huckleberry 
Finn was first published in England because someone had altered one of the illustrations in the American edition to give one of the men an erection. This gave us a problem in that we wanted to show this on television while trying to be discrete. So the camera slowly zoomed in and then faded at the last moment. I also made a programme on Edith Wharton, filming at her home, and one of John Cheever, talking to his wife and daughter who had just published a biography of her father in which she revealed his bisexuality. Naturally, her mother was proud that she had published a book but not pleased by its revelations. I was so nervous that my first question, on camera, began 'John Cheever was not a man to expose himself ...' I froze but then everyone started laughing, including wife and daughter.

BELLS: Your life long project on the two-volume biography of Arthur Miller has probably brought some special insights into the connection of this great dramatist and his works. Would you share with Belgrade BELLS some special moments you had experienced while working on it: the excitement while reading the documents...?

CHRISTOPHER BIGSBY: As to the biography of Miller, I had known him for many years. He didn't want a biography and I didn't want to write it, never having written one before. On the other hand I used to stay with him fairly frequently and he used to send me his new plays and I would send him a critique. One day, at a party, he introduced me as his biographer and I thought, "shit, now I'm going to have to write it.' He kept many boxes of material for me to sort through, so I would get up very early and work on it until lunch which his wife, the great Magnum photographer Inge Morath would prepare.

BELLS: On mentioning your name, what most scholars have in mind is your great contribution to American drama. Is it possible to rank American modern dramatists?

CHRISTOPHER BIGSBY: How do I rank American dramatists? Sometimes I don't think people realise how unique was the period between 1946 and 1959 which saw O'Neill's last great plays, Tennessee Williams best work and four Miller classic plays, plus the first work of Albee along with Hansberry 's Raisin in the Sun. Since then we saw Mamet and Shepard, the emergence of African-American writers. My top plays, though, would be Long Day's 
BELLS Interview: Christopher Bigsby

Journey into Night, A Streetcar named Desire and Death of a Salesman, but I imagine there would be few dissenters. In my new book I talk about nine new playwrights (seven of them women, two African-American and one Taiwanese-American) though I could have included many more if I had been allowed the space. There is, though, no standout playwright to put beside the classic figures, though Tracy Letts is a particular favourite.

BELLS: You have also told us much in your recent study 21st Century Television Drama about this genre. How do you see its future in comparison with theatre plays?

CHRISTOPHER BIGSBY: TV drama in America continues to flourish, though none with quite the bite of The Wire. I spend a lot of time watching American TV long-form dramas, too much time to tell the truth. The BBC has at long last awoken and is producing worthwhile drama. I think that the new American television drama has also played its part in stimulating excellent material from France, Sweden and Denmark.

\section{BELLS: Writers in Conversation with Christopher Bigsby in a few volumes must also have given you a lot of work and joy?}

CHRISTOPHER BIGSBY: Writers in Conversation originally included many of the interviews I did for the BBC. Subsequent volumes, however, were based on a literary festival which I have run at UEA for the last 24 years. That has, indeed, been a great pleasure. It has also been an education as I spend each summer reading my way through the work of writers from around the world ready for the festival in the autumn. There is a preponderance of British writers for obvious reasons but again it has become the basis for some friendships with writers as did the British Council Cambridge Seminar which I chaired for 18 years and which again led to friendships with writers, which has been one of the great pleasures of my life. As a result of meeting John Fowles at this, I accompanied him around Italy doing public interviews with him. He had had a stroke and after half an hour he would forget details of his books so that it was my job to help fill in any blanks. At one staged my wife insisted he should go back to our hotel to watch Norwich City who were playing Bayern Munich. It was not that she had any interest in football but our two sons were going to the match and she was convinced that she would see them in a cut away. Believe it or not, she did. The camera cut to the crowd, and there they were. 
BELLS: Among many awards there is one I must single out: you are also winner of the Betty Jean Jones Award for Outstanding Teacher of American Theatre and Drama. How important is teaching when compared with many other fields you have been dealing with?

CHRISTOPHER BIGSBY: I greatly enjoyed teaching, though I no longer do that, other functions having taken over (though I do supervise some undergraduate dissertations along with the occasional $\mathrm{PhD}$ ).

BELLS: You have won many awards for your non-fiction writing but you also won the McKitterick Prize for your first novel (of five), Hester, while your novel Beautiful Dreamer (2002) was an American Library Association Notable Book. TV plays, radio drama, short stories and poetry are other genres you have been sharing your imagination and craft with. Which is your dearest, most entertaining, painful ...?

CHRISTOPHER BIGSBY: As to novels, I wrote the first one not knowing whether it was any good. I got up at 6am every day and wrote 1000 words before breakfast, never re-reading. Finally, I finished and pressed the print button. In those days printing took an age so I took myself off to watch television. Uniquely, an agent took it and I had a publisher in days. This has never happened again. I wrote another, Beautiful Dreamer, in three weeks. That has never happened again. Indeed the publishing world has now become very difficult. I write for my own pleasure and as a break from other kinds of writing.

BELLS: Thank you for taking time to talk to Belgrade BELLS. 